\title{
DIGITAL SEED MORPHOMETRY FOR GENOTYPE IDENTIFICATION - CASE STUDY OF SEEDS OF EXCAVATED (15TH CENTURY HUNGARY) AND CURRENT VINEGRAPE (VITIS V. VINIFERA) VARIETIES
}

\author{
Z. Mravcsik ${ }^{1}$, F. Gyulai ${ }^{1}$, S. Vinogradov ${ }^{2}$, A. Emối ${ }^{1}$, I. Rovner ${ }^{4}$ and G. Gyulai ${ }^{1,3 *}$ \\ ${ }^{1}$ Institute of Environment and Landscape Management, Szent István University \\ H-2103 Gödöllö, Páter K. u. 1, Hungary; E-mail: mravcsikz@gmail.com \\ ${ }^{2}$ Institute of Economics, Law and Methodology, Szent István University \\ H-2103 Gödöllö, Páter K. u. 1, Hungary \\ ${ }^{3}$ Institute of Genetics and Biotechnology, Szent István University \\ H-2103 Gödölló, Páter K. u. 1, Hungary; E-mail: gyulai.gabor@mkk.szie.hu \\ ${ }^{4} 1902$ Alexander Road, Raleigh, NC 27608, USA
}

(Received 23 May, 2014; Accepted 21 August, 2014)

\begin{abstract}
Digital seed image analysis of seed remains of three ancient vinegrape samples excavated from 15th-century sites of Hungary was conducted and compared to those of ten currently grown old grapevine varieties. Digital seed images were analysed by Fovea Pro 4.0 computer program, with the final aim to identify the ancient grapevine cultivars with a final genotype reconstruction. Discriminant analysis, XY plot and histogram analyses revealed that seeds of two archaeological samples (11-13) show the closest similarity to the currently grown old vinegrape Vitis v. vinifera cv. 'Mézesfehér' (sample 6). Histogram analysis of seed parameter Equiv.Diam. $(\mathrm{cm})$ of the archaeological seed sample 'Budai vár' (sample 11) showed diverse multimodal distribution compared to the unimodal distribution of $\mathrm{cv}$. 'Mézesfehér' (sample 6), which results indicated that cv. 'Mézesfehér' went through a selection through the last five centuries, which narrowed the morphological diversity of this seed character.
\end{abstract}

Key words: cultivars, digital seed morphometry, excavated, genotype, grapevine, Vitis

\section{INTRODUCTION}

Species of Vitaceae plant family are woody climbers comprising of 17 genera (Acareosperma, Ampelocissus, Ampelopsis, Cayratia, Cissus, Clematicissus, Cyphostemma, Leea, Muscadinia, Nothocissus, Parthenocissus, Pterisanthes, Pterocissus, Rhoicissus, Tetrastigma, Yua and Vitis), with a total species number of 700 (Arnold et al. 2002, Chen and Manchester 2007). Most genera of Vitaceae have $2 \mathrm{n}=38$ chromosomes $(\mathrm{n}=19)$, however species of Ampelocissus, Ampelopsis, Muscadinia and Parthenocissus have $2 \mathrm{n}=40$ chromosomes $(\mathrm{n}=20)$, and species of the genus Cissus have $2 n=24$ chromosomes $(n=12)$. Genus Vitis consists of about sixty inter-fertile species, including about fifteen spe- 
cies of agronomic importance (Terral et al. 2010). Of them, grapevine (Vitis vinifera; $2 \mathrm{n}=4 \mathrm{x}=38$ ) has the most significant role. Genetically, vinegrape has a relatively small nuclear (nDNA) genome size (0.475-0.5-10 ${ }^{9}$ DNA bp), and regular sizes of cpDNA $(160,928 \mathrm{bp}$, NCBI \#DQ424856), and mtDNA $(773,279$ bp; NCBI \#FM179380) (Jansen et al. 2006). The wild, dioecious ancestor of $V$. $v$. sylvestris still co-exists in Eurasia and North Africa with the cultivated monoecious grapevine ( $V . v$. vinifera), which has bisexual flowers (Arnold et al. 2005, This et al. 2006). Dioecy in wild grapes seems to be encoded by a single gene; female individuals are homogametic, carrying homozygous recessive pistilsuppressor alleles $\left(\mathrm{Su}^{\mathrm{m} S \mathrm{u}^{\mathrm{m}}}\right)$, which suppress the development of anthers (and pollen). Male plants are heterozygous $\left(\mathrm{Su}^{\mathrm{F} S u^{\mathrm{m}}}\right)$, carrying a dominant pistilsuppressing $\mathrm{Su}^{\mathrm{F}}$ allele. Under domestication, the shift to a bisexual flower was attained by a single mutation to $\mathrm{Su}^{+}$, which is also dominant over $\mathrm{Su}^{\mathrm{m}}$, and resulted in two genotypes of monoecious grape types $\left(\mathrm{Su}^{+} \mathrm{Su}^{\mathrm{m}}\right.$ and $\left.\mathrm{Su}^{+} \mathrm{Su}^{+}\right)$ (McGovern 2004, Zohary et al. 2012).

By today, thousands of grapevine varieties and sports have been developed, which are generally classified in three main groups of Occidentalis group, which has the smallest berries and clusters developed in Western Europe; the Orientalis group, which has the largest berries with loose clusters developed in Asia; and the Pontica group, which has intermediate characteristics developed in Eastern Europe and the Black Sea Basin (Negrul 1946). Groups, according to the final consumptions, are the wine grapes, table grapes, seedless grapes and raisins (Terral et al. 2010).

There have been great efforts to find morphological and molecular markers to determine and discriminate vinegrape varieties. One of the morphological markers is based on seed morphology. Morphologically, it is easy to discriminate seeds of wild grape ( $V . v$. sylvestris) from those of cultivated grapevine ( $V . v$. vinifera) due to the lack of "seed stalk" of wild grape seeds. However, it is very difficult to discriminate seeds of vinegrape varieties based on further seed morphological characters of the pair of ventral infolds, the apical notch with raphe, and raphal ridge; and the dorsal chalazal scar, chalaza-base groove, and chalaza-apex groove (Chen and Manchester 2007) of the seeds (Hardie et al. 1996, Jacquat and Martinoli 1999, Rivera et al. 2007).

Structurally, Vitis seeds have a hard exocarp, with some exceptions with very soft seeds (Krochmal and Nawabi 1961). Soft seeded grapes were already reported by Plinius (in, Rivera et al. 2007). Old (Kolenati 1846) and current mutants (Ebadi et al. 1996) of seedless grapes obviously have no seeds. In cases of archaeological samples, seeds tend to lose exocarp, which provides "magic forms" (Gyulai 2011, Gyulai et al. 2011a, b).

Several seed parameters of size, shape, weight, length, diameter; and position/shape/size of the chalaza, raphe, infolds and seed beak were involved 
in a series of measurements (Andrasovszky 1915, 1917, 1925, Engelmann 1875, Facsar 1970, 1972a, b, 1975, Potebnja 1911, Terpó 1976, 1977, Troshin et al. 1990). Derived seed parameters also were formulated, e.g. seed width divided by seed length (Stummer 1911), size ratios of seed parameters (Mangafa and Kotsakis 1996), and elliptic Fourier transformation (Milanesi et al. 2011, Terral et al. 2010). All these measurements provided huge data for Vitis taxonomy, and became useful for identification of excavated seed remains (Gyulai et al. 2011a, b, Milanesi et al. 2011, Orrù et al. 2013). However, these data were taken by individual seed measurements on relatively small seed populations.

Recently, a new method of computer assisted seed morphometry has been developed based on digital image analysis of the seeds using computer programs, e.g. Fovea Pro 4.0 (Russ 2005, 2007), ImageJ (Chen and Manchester 2007, Rasband 1997-2006), and KS-400V.3.0 (Carl Zeiss, Germany) (Orrù et al. 2013), which methods allowed to measure hundreds of seed populations at a time. The computer assisted digital seed morphometry have already provided several important and basic knowledge in plant evolution and domestication (Rovner 2011, Rovner and Gyulai 2007), plant taxonomy (Brinkkemper et al. 2011), and arhaeobotany (Gyulai 2012a, b, Orrù et al. 2013, Rovner et al. 2013).

Here we aimed to discriminate, and identify three ancient grapevine specimens excavated from the Middle Ages (15th cent.), Hungary, by digital seed morphometry. For control, we used visually preselected seed populations of ten currently grown old grapevine cultivars from Hungary.

\section{MATERIALS AND METHODS}

Seeds of ten old current grapevine varieties were collected according to the historical indications: 1: Vitis v. vinifera 'Bakator'; 2: V. v. v. 'Gohér'; 3: V. v. v. 'Furmint'; 4: V.v. v. 'Kéknyelü'; 5: $V . v$. v. 'Lisztes fehér'; 6: $V . v$. v. 'Mézesfehér'; 7: V.v.v. 'Csókaszőlo”'; 8: V.v. v. 'Szürkebarát'; 9: V.v.v. 'Zöldszilváni'; 10: V. v. v. 'Kecskecsöcsü'.

Excavated and wet-sieved sediment samples of three excavation sites were processed by floatation followed by seed sorting and identification of grapevine seeds in the laboratory according to Schermann (1966): 11: seed remains excavated at Royal Palace, Dísz tér, Buda, 15th cent. (determined by B. Hartyányi) (35 seeds); 12: seed remains excavated at Kölcsey Cultural Centre, Debrecen, 15th cent. (2 seeds); and 13: seed remains excavated at Debrecen, 15th cent. (3 seeds).

Digital photos (pdf) of two hundred seeds of each current vinegrape, and all of the possible excavated seed remains were taken by Canon scanner, and pdf photos were processed by Fovea Pro 4.0 computer program (Russ 2005, 2007). In total 33 parameters were measured: Adjusted_Count.; Area $\left(\mathrm{cm}^{2}\right)$; 

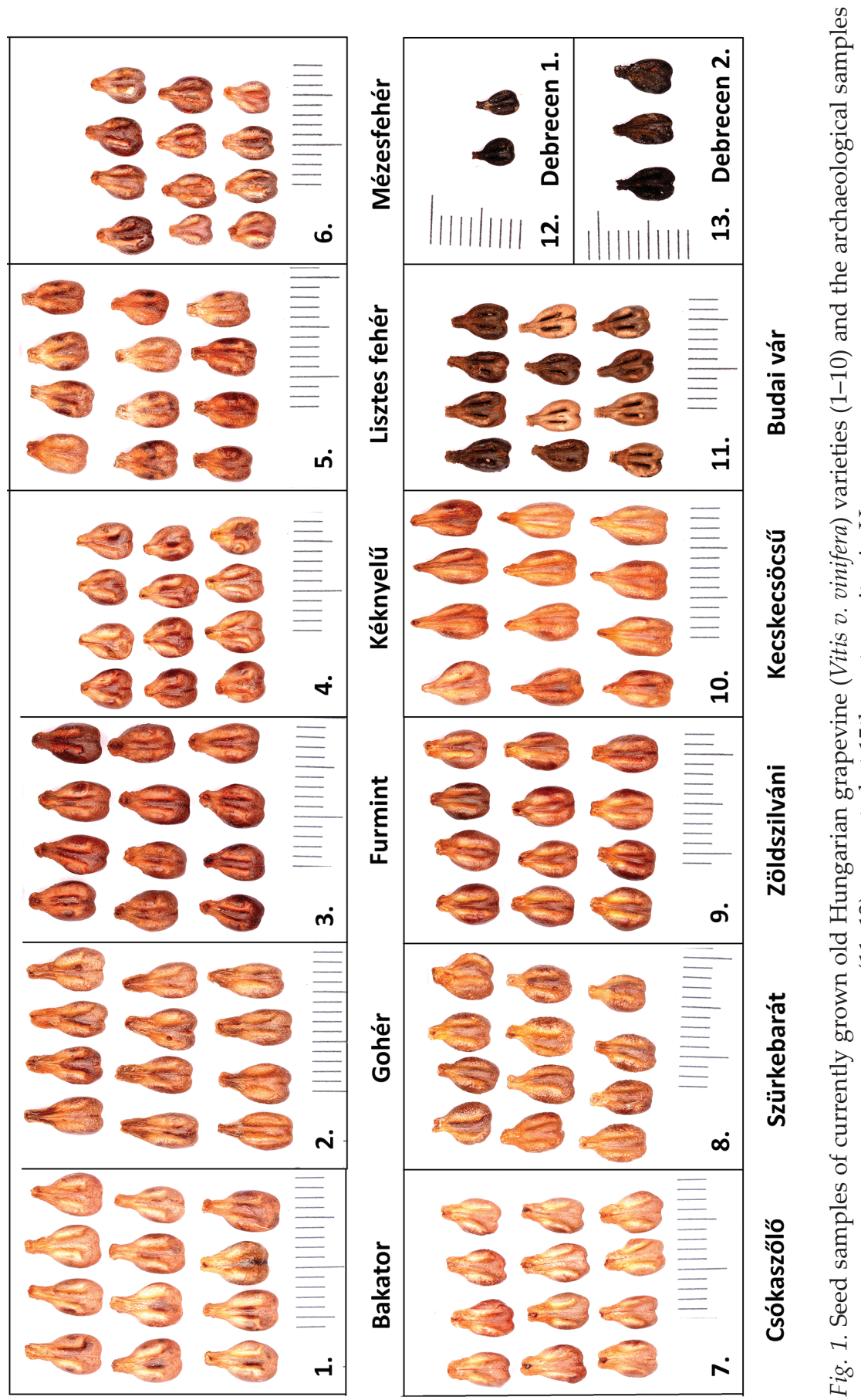
Aspect Ratio; Breadth (cm); Circum.Rad. $(\mathrm{cm})$; Convex Area $\left(\mathrm{cm}^{2}\right)$; Convex Perim. (cm); Convexity; Elongation; Equiv.Diam. (cm); External Perim. $(\mathrm{cm})$; Filled Area $\left(\mathrm{cm}^{2}\right)$; FormFactor; Fractal Dim.; Inscrib.Rad. $(\mathrm{cm})$; Length $(\mathrm{cm})$; Mean_Ext.Bran.Len. (cm); Mean_Fiber Width (cm); Moment_Angle; Perimeter (cm); Radius Ratio; Roundness; Skel.Branch_Points; Skel.End_Points; Skeleton Length (cm); Solidity; Symmetry; Width_Std.Dev. (cm); X-Centroid $(\mathrm{cm})$; X-Geom.Center $(\mathrm{cm})$; X-Weighted_CG $(\mathrm{cm})$; Y-Centroid $(\mathrm{cm})$; Y-Geom. Center $(\mathrm{cm})$; Y-Weighted_CG $(\mathrm{cm})$. Background of photos was processed first by "magic wand", selected and cleared, "black and white bitmap" was converted, and "remove scratches and dust" was used, finally glowing spots on seeds were removed by tools of "fill holes".

For cluster (Ward Linkage) analysis, canonical discriminant analysis, and factor analysis the SPSS program package was used. XY plots and histograms were edited by Microsoft Excel program.

\section{RESULTS}

\section{Seed samples}

Digital photos (Fig. 1) of the ten old current vinegrape (Vitis v. vinifera) varieties (1-10) (200 seeds each) and the archaeological specimens (11-13) were taken by Canon scanner and, analysed by Fovea Pro 4.0 program. Data of the 33 parameters were forwarded for discriminant analysis.

\section{Cluster and discriminant analysis}

Cluster analysis of the total parameters measured grouped all archaeological samples (11-13) in one cluster (Fig. 2). Currently grown old Vitis varieties were clustered in two further clusters (Fig. 2).

Discriminant analysis revealed that the first two functions comprise seven and four main parameters, respectively. Function1: Circum.Rad. (cm): 0.771*; Length $(\mathrm{cm}): 0.765^{*}$; Perimeter $(\mathrm{cm}): 0.705^{*}$; External Perim. $(\mathrm{cm})$ : 0.705* FormFactor: $-0.690^{*}$; Convex Perim. $(\mathrm{cm})$ : $0.685^{*}$; Skeleton Length (cm): 0.419*. Function2: Equiv.Diam. (cm): $-0.618^{*}$; Filled Area $\left(\mathrm{cm}^{2}\right):-0.573^{*}$; Area $\left(\mathrm{cm}^{2}\right):-0.573^{*}$; Convex Area $\left(\mathrm{cm}^{2}\right):-0.559^{*}$.

The Function 1 parameters characteristically discriminated the archaeological sample 12 (Kölcsey Cultural Centre, Debrecen) from all the other samples (Fig. 3).

Along the Function2, centroids (a type of mean values) of archaeological samples 11 ('Buda') and 13 ('Debrecen') showed the closest distances to the currently grown old grapevine Vitis v. vinifera 'Mézesfehér' (sample 6) (Fig. 3). 


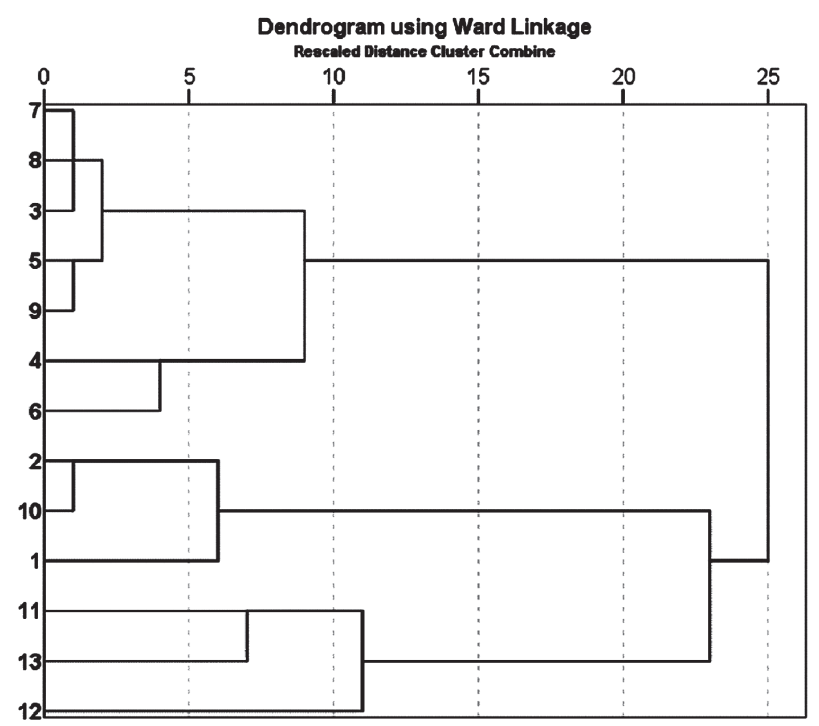

Fig. 2. Cluster Analysis (SPSS, Ward Linkage) of the total digital seed morphometry data (Fovea Pro 4.0) of seed populations (200 each) of currently grown old Hungarian grapevine (Vitis v. vinifera) varieties (1-10) and compared to the archaeological samples (11-13) excavated at 15 th-century sites in Hungary. The three main clusters are indicated

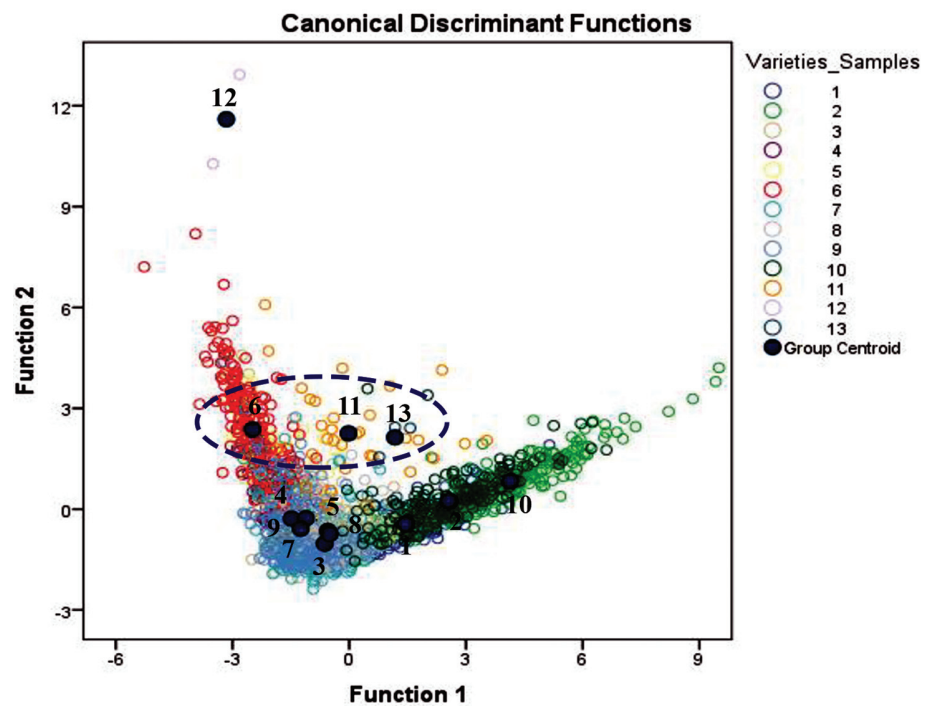

Fig. 3. Discriminat analysis (SPSS) of digital seed morphometry data (Fovea Pro 4.0) of seed populations (200 each) of currently grown old Hungarian grapevine (Vitis v. vinifera) varieties (1-10) and compared to archaeological samples (11-13) excavated at 15th-century sites in Hungary. Centroids (a type of mean values) of samples 6, 11 and 13 are indicated 
The 35 seed remains of the archaeological sample 11 ('Buda') allowed us to conduct further analysis of $X Y$ plots with now deeper discrimination result (Fig. 4). However, the archaeological sample 12 (two seed remains) get separated also with seeds of sample 6 .

Histogram analysis of Equiv.Diam. $(\mathrm{cm})$ indicated that the archaeological sample 11 ('Buda') has a multimodal distribution compared to sample 6 ('Mézesfehér'), which showed unimodal distribution (Fig. 5).

\section{DISCUSSION}

Archaeobotanical records of vinegrape

The oldest (8,400 B.P.) wild grape (Vitis v. sylvestris) seeds (about $3 \mathrm{~mm}$ long) were excavated in Turkey, at Nevali Çori (NÇ) located near the Turkish city of Urfa ( $37^{\circ} 60^{\prime} \mathrm{N}, 38^{\circ} 70^{\prime} \mathrm{E}, 490 \mathrm{~m}$ above sea level) on the slope of a Euphrates side valley, Hilvan Province (Hauptmann 1997, Pasternak 2008).

The first convincing evidence of grapevine (Vitis $v$. vinifera) seeds, with indications of grape cultivation, were also uncovered in Turkey at Kurban Höyük (5,700-5,200 B.P. non-calibrated radiocarbon time) (McGovern 2004,

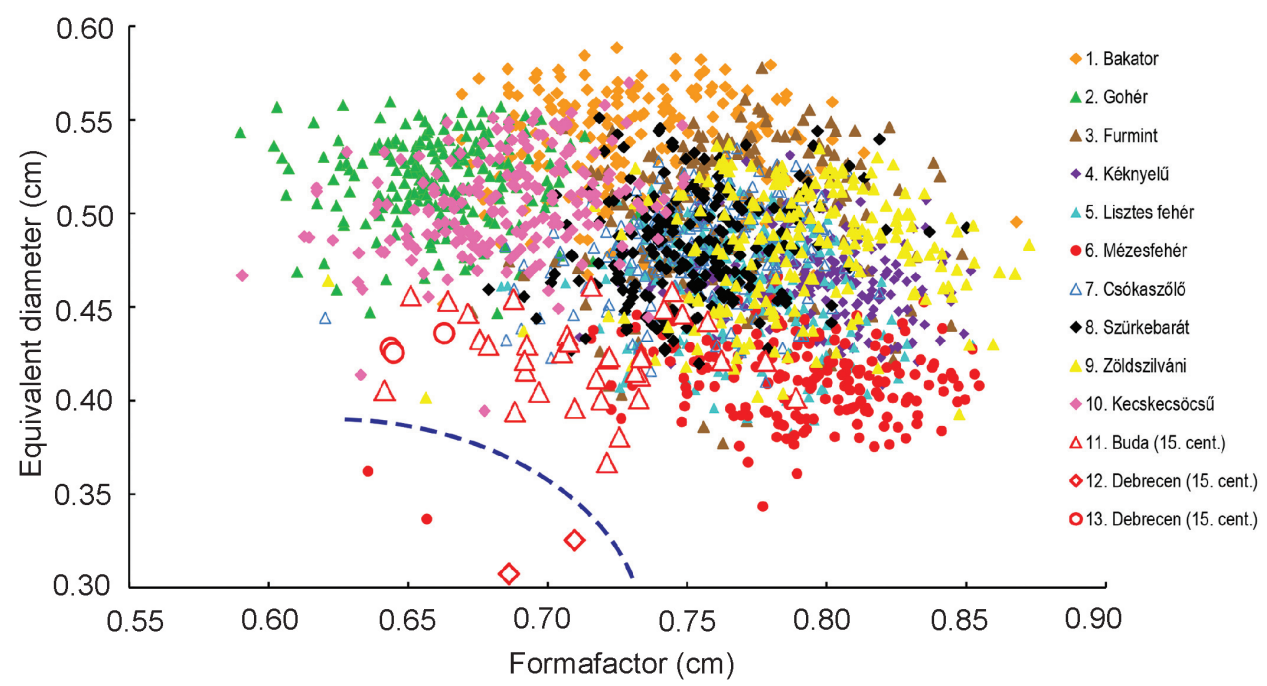

Fig. 4. XY plot (Microsoft Excel) of digital (Fovea Pro 4.0) seed morphometry data (Equiv. Diam. (cm) vs. FormFactor(cm)) of seed populations (200 each) of currently grown old Hungarian grapevine (Vitis v. vinifera) varieties (1-10) and compared to archaeological samples (11-13) excavated at 15th-century sites in Hungary. Groups of seed samples of 12 and 6 are indicated (parameter Equiv.Diam. $(\mathrm{cm})$ reflects the diameter of a circle with the same area as the seed and FormFactor is calculated as $4 \pi x$ seed Area/seed Perimeter2) 

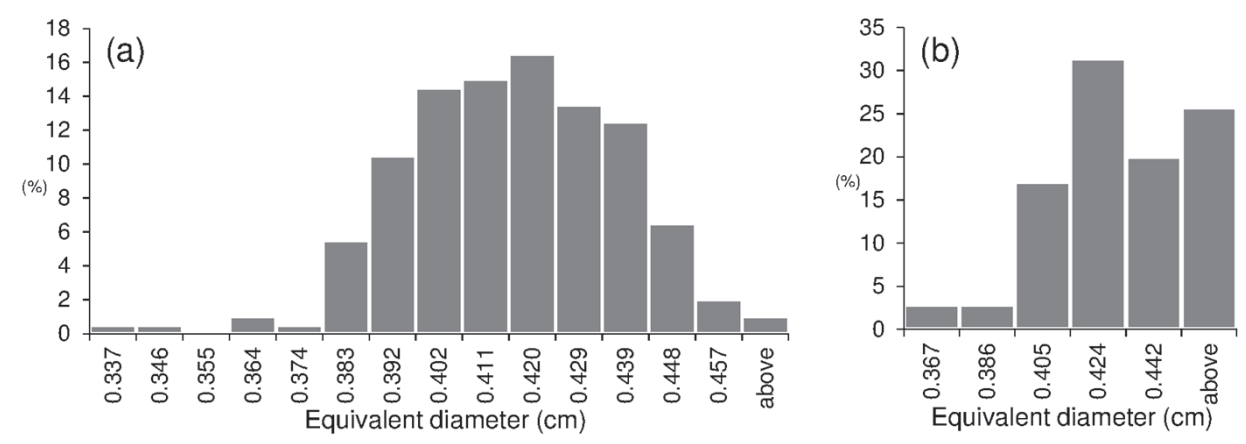

Fig. 5. Histogram analysis (Microsoft Excel) of the seed parameter Equiv.Diam. $(\mathrm{cm})$ of the currently grown old grapevine cv. 'Mézesfehér' (sample 6) (a), and compared to the archaeological grapevine 'Buda' (sample 11) (b)

Zohary et al. 2012), and early Bronze Age (3,200-1,900 B.P.) sites along the Jordan Valley, at Tell Shuna (Jordan; Chalcolithic), Jericho (Cisjordan; early Bronze Age), and Arad (Israel; early Bronze Age) (Jacquat and Martinoli 1999). Ancient grape seeds were also excavated at Semma (Sudan) 3,500 B.P. (Zeist 1983).

The earliest evidence of wine production (jars from Godin) was found in Iran (Hajji Firuz Tepe site in the Zagros Mountains) about 7,400-7,000 B.P. (This et al. 2006), and 5,500-4,900 B.P. (McGovern 2004). Later, Greek, Latin, and Egyptian vine amphoras with jellified vine remains were also found in the hulls of sunken ships (McGovern 2004), similar to the famous shipwreck remains at Uluburun, near Kas (Turkey) (Ward 2003). Grape cultivation gradually spread to Mesopotamia, Assyria, and Egypt (about 5,500-5,000 B.P.), and further west along the Mediterranean to Phoenicia, Greece, North Africa and then to the entire Roman Empire north to Pannonia (Hungary) and German tribes. Viticulture also spread eastward along the Silk Road and it reached China and Japan in 3,200 B.P. (Gyulai et al. 2011a, b, Núñez and Walker 1989).

Grapevine was introduced to the Americas by colonists either by the early Chinese explorer Zheng He (1405-1435), or by the Columbus voyages (first: 3 August 1492 to 15 March 1493; second: 25 September 1493 to 11 June 1495; third: 30 May 1498 to 15 November 1500; fourth: 11 May 1502 to 7 November 1504). The first plantations in North America were established on the West Coast by Spanish missionaries and later by viticulturists like Ágoston Haraszty, who is considered the father of California's grape-growing industry. Haraszty imported 200,000 grape cuttings from Europe after 1849, including grape varieties from his native Hungary, and developed over half a million California acres to viticulture, making wine growing second only to orange production in the state's agricultural economy. In recognition of his merits, 
Haraszty was named California's State Commissioner of Viticulture (Sisa 2006).

In Hungary, the oldest wild grape seeds excavated in Hungary (Berettyóúffalu, Körös Culture, 6,000 BCE) were found to be 8,000-year-old (Vitis v. sylvestris) (Gyulai et al. 2011a, b), and the earliest grapevine (Vitis v. vinifera) seeds were found in Sopron (Hungary) (1,300 BCE), which dates the origins of grape cultivations to the late Bronze Age in the Carpathian Basin, Central Europe. The earliest wine residue in Hungary dates back to 700 BCE (Fehérvárcsurgó), which places the beginnings of wine-making to the Iron Age, long before the Roman period (Gyulai 2010, Gyulai et al. 2011a).

\section{Seed morphometry and digital image analysis}

Genetic analyses (Manen et al. 2003, Núñez and Walker 1989), and variety reconstructions of excavated seed remains (Bisztray et al. 2004, Gyulai et al. 2001, 2006, 2009, 2012a, b, Lágler et al. 2005, Szabó et al. 2005) provided numerous new data to understand plant domestications and genotype resurrections.

Recent applications of robust digital (Neef et al. 2011) and computer-assisted morphometry (Orrù et al. 2007, Russ 2005, 2007) have resulted in the creation of variametric analysis, a powerful new approach to the study of botanical systematics, archaeobotany and archaeogenetics using analysis of patterns of variation in seed morphology (Brinkkemper et al. 2011, Rovner 2011, Rovner and Gyulai 2007, Rovner et al. 2013). It is objective, quantitative, precise, quick, accessible and cost-effective. Botanical variametry can detect and/ or measure such Darwinian factors as diversity, natural selection, adaptability, vulnerability to environmental changes, human selection (i.e. domestication), and assessments of phenovariation and genovariation in plants (Rovner et al. 2013). This technology has revealed, that unlike previous assumptions, natural variation is not normally distributed rather they show multimodal distribution, while size and shape parameters of domesticated cereal seeds shift toward natural distribution (syn.: normal, Gaussian distribution, bell shaped curve, unimodal distribution) under human selection, and domesticated cereals show unimodal distribution (Rovner and Gyulai 2007). However, seed parameters of Myosotis (a dicot genus of wild plants) also showed unimodal distribution (Brinkkemper et al. 2011). A recent study also aimed to measure the force of mutation (variation) vs. force of selection by analysis of seed parameters of four dioecious plants (Asparagus, Diospyros, Hippophäe, and Taxus) (Rovner et al. 2013).

Here we used digital seed morphometry to discriminate, and identify three ancient grapevine specimens excavated from the Middle Ages (15th cent.), Hungary with control ten old current grapevine cultivars grown in 
Hungary (Fig. 1). In a current study, ancient seed remains from BC periods (from the 23rd cent. to the 10th cent. BC) were compared to eleven recently grown cultivars (Milanesi et al. 2011).

Cluster analysis (Fig. 2) of our study grouped all archaeological samples in one cluster. Archaeological seed samples were also grouped in one cluster in the study of (Milanesi et al. 2011), which data may indicate a general seed shrinking of the archaeological seed samples, however ratios of shape parameters may persists at lower levels.

In total, 33 seed parameters were measured in our study, of them only eleven were grouped in the first and second functions of discriminant analysis: Function1: Circum.Rad. $(\mathrm{cm})$, Length $(\mathrm{cm})$, Perimeter $(\mathrm{cm})$, External Perim. (cm), FormFactor, Convex Perim. $(\mathrm{cm})$, Skeleton Length $(\mathrm{cm})$; Function2: Equiv.Diam. $(\mathrm{cm})$, Filled Area $\left(\mathrm{cm}^{2}\right)$, Area $\left(\mathrm{cm}^{2}\right)$, and Convex Area $\left(\mathrm{cm}^{2}\right)$. It revealed that archaeological sample 11 ('Buda') and 13 ('Debrecen') showed the closest distances to the currently grown old grapevine Vitis $v$. vinifera $\mathrm{cv}$. 'Mézesfehér' (sample 6) (Fig. 3). This result may indicate the same origin and genotype of these archaeological samples. By accepting this indication we assume that the currently grown old grapevine cultivar 'Mézesfehér' survived the phylloxera (an insect pest) in Hungary, which devastated the European vineyards in the 1880s (This et al. 2006), and this results can also indicate the importance of replantations of this old grapevine varieties.

In a study using KS-400V.3.0 program (Carl Zeiss, Germany) thirteen seed shape and size parameters of the total 93 measured characters were found to be discriminative (Orrù et al. 2013). Of the thirteen parameters the perimeter ratio $\left(\mathrm{P}_{\text {conv }} / \mathrm{P}_{\text {crof }}\right)$, maximum diameter $\left(\mathrm{D}_{\max }\right)$, feret ratio $\left(\mathrm{D}_{\min } / \mathrm{D}_{\max }\right)$, equivalent circular diameter (Ecd), and convex perimeter (Pconv) were found the most discriminative (Orrù et al. 2013).

In the histogram analysis (Fig. 5) the seed parameter Equiv.Diam. (cm) of the archaeological sample 11 ('Buda') showed diverse multimodal distribution compared to the unimodal distribution of sample 6 ('Mézesfehér'). These results indicate that 'Mézesfehér' went through a selection (Rovner and Gyulai 2007) through the last five centuries, which narrowed the diversity of this seed character.

By using large (200 seeds) seed populations we may also have provided further resolution to the fundamental shortage of seed morphometry, which are the fact that seeds may not represents the same ripened/developmental stages, and that seeds may differ in size and shape according to their positions in the berry (Facsar 1972a).

To conclude, our results indicate the power of the digital seed morphometry to identify and reconstruct ancient Vitis varieties from seed remains. This method was also found to scale the level of domestication of Vitis varieties. 
Acknowledgements - The research was funded by the project "Excellence in Faculty Research Support-Research, Centre of Excellence 17586-4/2013/TUDPOL" SZIE MKK, Gödöllő, Hungary.

\section{REFERENCES}

Andrasovszky, J. (1915): A szőlőmagvak diagnosztikus értéke. (Der diagnostische Wert der Traubensamen). - Borászati Lapok 47: 39.

Andrasovszky, J. (1917): A szőlőmagvak diagnosztikus értéke. (Der diagnostische Wert der Traubensamen). - Ampel. Int. Évk. 6: 49-59.

Andrasovszky, J. (1925): Szőlő. - In: Jávorka, S. (ed.): Magyar Flóra. Studium, Budapest, pp. 701-708.

Arnold, C., Rosetto, M., McNalley, J. and Henry, R. J. (2002): The application of SSRs characterized for grape (Vitis vinifera) to conservation studies in Vitaceae. - Amer. J. Bot. 89: 22-28. doi: 10.3732/ajb.89.1.22

Arnold, C., Schnitzler, A., Douard, A., Peter, R. and Gillet, F. (2005): Is there a future for a wild grapevine (Vitis vinifera subsp. silvestris) in the Rhine Valley? - Biodiversity and Conservation 14: 1507-1523. doi: 10.1007/s10531-004-9789-9

Bisztray, Gy. D., Bacsó, R., Bodor, P., Facsar, G., Gyulai, F. and Velich, I. (2004): Archaeobotanical and genetical methods to analyse 600-year-old seeds of horticultural plants. - Book of abstracts, 5th IVCHB Symposium, In vitro culture and horticultural breeding, 12-17 September 2004, Debrecen, Hungary, p. 212.

Brinkkemper, O., der Maaten, L. and Boon, P. (2011): Identification of Myosotis seeds by means of digital image analysis. - Veg. Hist. Archaeobot. 20: 435-445. doi: 10.1007/ s00334-011-0313-3

Chen, I. and Manchester, S. R. (2007): Seed morphology of modern and fossil Ampelocissus (Vitaceae) and implications for phytogeography. - Amer. J. Bot. 94: 1534-1553. doi: 10.3732/ajb.94.9.1534

Ebadi, A., Sedgley, M., May, P. and Coombe, B. G. (1996): Seed development and abortion in Vitis vinifera L. cv. Chardonnay. - Int. J. Plant Sci. 157: 703-712. doi: 10.1086/297392

Engelmann, G. (1875): Synopsis of American grapevines. - Bushberg Catalogue, Bushberg, MO, USA, pp. 4-11.

Facsar, G. (1970): Habitus studies on seeds Vitis vinifera L. sorts. - Acta Agr. Hung. 19: 403-406.

Facsar, G. (1972a): Makroszkopikus szerkezeti vizsgálatok Vitis vinifera L. fajták érő bogyóin. - Kertészeti Egyetem Növénytani Tanszék Közlem. 35: 147-158.

Facsar, G. (1972b): A kerti szőlő (Vitis vinifera L.) fajtáinak magtípus rendszere. - Kertészeti Egyetem Növénytani Tanszék Közlem. 35: 191-216.

Facsar, G. (1975): Agricultural-botanical analysis of the medieval grape seeds from the Buda castle hill. - Mitt. Archäolog. Inst. Ungar. Akad. Wiss. 4: 157-173.

Gyulai, F. (2010): Archaeobotany in Hungary. Seed, fruit, food and beverage remains in the Carpathian Basin: an archaeobotanical investigation of plant cultivation and ecology from the Neolithic until the Late Middle Ages. - Archaeolingua, Budapest, 479 pp.

Gyulai, F., Kenéz, Á. and Pető, Á. (2011a): Chapter 4: Morphogenetics of seeds and plant remains in the Carpathian Basin from the Neolithic to the late Medieval Age (8000 B.P. to 17th cent 
CE). - In: Gyulai, G. (ed.): Plant archaeogenetics. Nova Science Publisher Inc., New York, USA, pp. 31-39.

Gyulai, G. (ed.) (2011): Plant archaeogenetics. - Nova Science Publisher Inc., New York, USA, $168 \mathrm{pp}$.

Gyulai, G., Horváth, L., Lágler, R. and Holly, L. (2012a): The Hungarian gene bank collections of common millet (Panicum miliaceum) and the application for conservation genetics. - Europ. J. Plant Sci. Biotechnol. 6(SI2): 69-102.

Gyulai, G., Malone, R. P., Waters, L. Jr., Heszky, L. and Kiss, E. (2011b): Chapter 5: Morphogenetics of ancient Vitis seeds from antiquity (3rd and 11-15th cents Hungary): a genotype reconstruction. - In: Gyulai, G. (ed.): Plant archaeogenetics. Nova Science Publisher Inc., New York, USA, pp. 41-48.

Gyulai, G., Magda, A., Kiss, J., Gyulai, F., Holly, L. and Heszky, L. (2001): DNS-izolálás és PCR-amplifikáció 700 éves növényi magvakból. - VII. Növénynemesítési Tudományos Napok, Budapest, p. 89.

Gyulai, G., Szabó, Z., Wichmann, B., Bittsánszky, A., Waters, L. Jr., Tóth, Z. and Dane, F. (2012b): Conservation genetics, heat map analysis of nuSSRs of aDNA of archaeological watermelons (Cucurbitaceae, Citrullus 1. lanatus) compared to current varieties. - Genes, Genomes and Genomics 6(SI1): 86-96.

Gyulai, G., Tóth, Z., Szabó, Z., Gyulai, F., Lágler, R., Kocsis, L. and Heszky, L. (2009): Domestication events of grape (Vitis vinifera) from antiquity and the Middle Ages in Hungary from growers' viewpoint. - Hung. Agric. Res. 2009(3-4): 8-12.

Gyulai, G., Humphreys, M., Lágler, R., Szabó, Z., Tóth, Z., Bittsánszky, A., Gyulai, F. and Heszky, L. (2006): Seed remains of common millet from the 4th (Mongolia) and 15th (Hungary) centuries; AFLP, SSR, and mtDNA sequence recoveries. - Seed Sci. Res. 16: 179-191. doi: 10.1079/SSR2006251

Hardie, W. J., O'Brien, T. P. and Jaudzems, V. G. (1996): Morphology, anatomy and development of the pericarp after anthesis in grape, Vitis vinifera L. - Austral. J. Grape and Wine Res. 2(2): 97-142. doi: 10.1111/j.1755-0238.1996.tb00101.x

Hauptmann, H. (1997): Nevali Çori. - Oxford Encycl. Archaeol. Near East 4: 131-134.

Jacquat, C. and Martinoli, D. (1999): Vitis vinifera L. Wild or cultivated? Study of the grape pips found at Petra, Jordan; 150 B.C.-A.D. 400. - Veg. Hist. Archaeobot. 8: 25-30. doi: 10.1007/BF02042839

Jansen, R. K., Kaittanis, C., Saski, C., Lee, S.-B., Tomkins, J., Alverson, A. J. and Daniell, H. (2006): Phylogenetic analyses of Vitis (Vitaceae) based on complete chloroplast genome sequences: effects of taxon sampling and phylogenetic methods on resolving relationships among rosids. - BMC Evol. Biol. 6: 32. doi: 10.1186/1471-2148-6-32

Kolenati, F. A. (1846): Versuch einer systematischen Anordnung der in Grusinien einheimischen Reben nebst einem oekonomisch-technischen Anhange. - Bull. Soc. Sci. Nat. Moscou 19: 283-371.

Krochmal, A. and Nawabi, A. (1961): A descriptive study of the grapes of Afghanistan. Vitis 2: 241-256.

Lágler, R., Gyulai, G., Humphreys, M., Szabó, Z., Horváth, L., Bittsánszky, A., Kiss, J., Holly, L. and Heszky, L. (2005): Morphological and molecular analysis of common millet (P. miliaceum) cultivars compared to an aDNA sample from the 15th century (Hungary). - Euphytica 146: 77-85. doi: 10.1007/s10681-005-5814-7

Manen, J.-F., Bouby, L., Dalnoki, O., Marinval, P., Turgay, M. and Schlumbaum, A. (2003): Microsatellites from archaeological Vitis vinifera seeds allow a tentative assignment 
of the geographical origin of ancient cultivars. - J. Archaeol. Sci. 30: 721-729. doi: 10.1016/S0305-4403(02)00244-3

Mangafa, M. and Kotsakis, K. (1996): A new method for the identification of wild and cultivated charred grape seeds. - J. Archaeol. Sci. 23: 409-418. doi: 10.1006/jasc.1996.0036

McGovern, P. E. (2004): Ancient wine: the search for the origins of viniculture. - Princeton University Press, Princeton, NJ, USA, 365 pp.

Milanesi, C., F., Antonucci, P., Menesatti Costa, C., Faleri, C. and Cresti, M. (2011): Morphology and molecular analysis of ancient grape seeds. - Interdiscipl. Arch. Nat. Sci. Archaeol. 2: 95-100.

Neef, R., Cappers, R. T. J. and Bekker, R. M. (2011): Digital atlas of economic plants in archaeology. - Barkhuis Publishing and the Groningen University Library, The Netherlands, $760 \mathrm{pp}$.

Negrul, A. M. (1946): Ampelography of USSR. Vol. I. - Moscow, 420 pp.

Núñez, R. D. and Walker, M. J. (1989): A review of palaeobotanical findings of early Vitis in the Mediterranean and the origins of cultivated grapevines, with special reference to new pointers to prehistoric exploitation in the western Mediterranean. - Rev. Palaeobot. Palynol. 61: 205-237. doi: 10.1016/0034-6667(89)90033-X

Orrù, M., Grillo, O., Lovicu, G., Venora, G. and Bacchetta, G. (2013): Morphological characterisation of Vitis vinifera L. seeds by image analysis and comparison with archaeological remains. - Veg. Hist. Archaeobot. 22: 231-242. doi: 10.1007/s00334-012-0362-2

Pasternak, R. (2008): Investigations of botanical remains from Nevali Çori PPNB, Turkey: a short interim report. - http://www.bioversityinternational.org.

Potebnja, A. (1911): Semena evropejskich sortov vinograda i ich znacenie dl'a klassifikacii. - Trudy Bjuro Prikl. Bot. St. Petersburg 3: 147-158.

Rasband, W. S. (1997-2006): ImageJ. - US Institutes of Health, Bethesda, MD, USA. Website: http://rsb.info.nih.gov/ij/

Rivera, D., Miralles, B., Obón, C., Carreno, E. and Palazón, J.A. (2007): Multivariate analysis of Vitis subgenus Vitis seed morphology. - Vitis 46: 158-167.

Rovner, I. (2011): Chapter 12: Computer-assisted seed morphometry - a tool for archaeogenetics. - In: Gyulai, G. (ed.): Plant Archaeogenetics. Nova Science Publisher Inc., New York, USA, pp. 135-141.

Rovner, I. and Gyulai, F. (2007): Computer-assisted morphometry: a new method for assessing and distinguishing morphological variation in wild and domestic seed populations. - Economic Bot. 61: 154-172. doi: 10.1663/0013-0001(2007)61[154:CMANMF]2 $.0 . \mathrm{CO} ; 2$

Rovner, I., Gyulai, G., Mravcsik, Z., Gyulai, F., Emődi, A., Kerti, B. and Vinogradov, S. (2013): Variametric analysis: a new method in the study of diversity and unpredictability in the biological world. - Book of abstracts, CBB2, 2nd Conference of cereal biotechnology and breeding, 5-7 November, Budapest, pp. 67-68.

Russ, J. (2005): Fovea Pro 4.0 Computer software. - Reindeer Graphics. Website: www.reindeergraphics.com

Russ, J. (2007): The image processing handbook. 5th ed. - CRC Press, Boca Raton, FL, USA, 685 pp.

Schermann, Sz. (1966): Magismeret. (Seed morphology). 1-2. - Akadémiai Kiadó, Budapest, 861 pp., 209 pp.

Sisa, S. (2006): The spirit of Hungary. - Vista Books, Morristown, NJ, USA, 374 pp.

Stummer, A. (1911): Zur Urgeschichte der Rebe und des Weinbaues. - Mitt. Anthropol. Gesellsch. Wien 41: 283-296. 
Szabó, Z., Gyulai, G., Humphreys, M., Horváth, L., Bittsánszky, A., Lágler, R. and Heszky, L. (2005): Genetic variation of melon (C. melo) compared to an extinct landrace from the Middle Ages (Hungary) I. rDNA, SSR and SNP analysis of 47 cultivars. - Euphytica 146: 87-94. doi: 10.1007/s10681-005-5685-y

Terpó, A. (1976): The carpological examination of wild-growing vine species of Hungary. I. - Acta Bot. Acad. Sci. Hung. 22: 209-247.

Terpó, A. (1977): The carpological examination of wild-growing vine species of Hungary. II. Qualitative and quantitative characteristics of vine seeds. - Acta Bot. Acad. Sci. Hung. 23: 247-273.

Terral, J.-F., Tabard, E., Bouby, L., Ivorra, S., Pastor, T., Figueiral, I., Picq, S., Chevance, J.-B., Jung, C., Fabre, L., Tardy, C., Compan, M., Bacilieri, R., Lacombe, T. and This, P. (2010): Evolution and history of grapevine (Vitis vinifera) under domestication: New morphometric perspectives to understand seed domestication syndrome and reveal origins of ancient European cultivars. - Ann. Bot. 105: 443-455. doi: 10.1093/ aob/mcp298

This, P., Lacombe, T. and Thomas, M. R. (2006): Historical origins and genetic diversity of wine grapes. - Trends in Genetics 22: 511-519. doi: 10.1016/j.tig.2006.07.008

Troshin, L., Nedov, P., Litvak, A. and Guzun, N. (1990): Improvement of Vitis vinifera sativa DC. taxonomy. - Vitis (spec. issue): $37-43$.

Ward, C. (2003): Pomegranates in eastern Mediterranean contexts during the Late Bronze Age. - World Archaeol. 34: 529-541. doi: 10.1080/0043824021000026495

Zeist, van W. (1983): Fruits of foundation deposits of two temples. - J. Archaeol. Sci. 10: 351-354.

Zohary, D., Hopf, M. and Weiss, E. (2012): Domestication of plants in the Old World. - Oxford University Press, Oxford, 243 pp. 